\title{
Effects of Acute Ethanol Exposure upon In Vivo Leucine Uptake and Protein Synthesis in the Fetal
} Rat

\author{
STANLEY E. FISHER ${ }^{(34)}$ MARY ANNE BARNICLE, BECKY STEIS, IAN HOLZMAN, AND DAVID H \\ VAN THIEL \\ Departments of Pediatrics [S. E. F., M. A. B., B. S. I. H.] and Medicine, [D. H. V. T.] University of Pittsburgh \\ School of Medicine and Children's Hospital of Pittsburgh, Pittsburgh, Pennsylvania. USA
}

\begin{abstract}
Summary
Tritiated L-leucine $\left(\left[^{3} \mathrm{H} \mid \mathrm{L}-\mathrm{leu}\right)\right.$ was injected into the amniotic sacs of 19-day gestation rat fetuses during a brief (4-hr) period of elevation in maternal serum ethanol. The pregnant rats received $47.5 \%$ ethanol at "high dose" ( 0.29 to $0.33 \mathrm{~g} / 100 \mathrm{~g}$ body weight) or "low dose" ( 0.12 to $0.14 \mathrm{~g} / 100 \mathrm{gm}$ body weight) by intraperitoneal injection. Fetal brain and liver were removed and analyzed for tissue uptake (TU) and protein incorporation (PI) of $\left.\right|^{3} \mathrm{H} \mid \mathrm{L}$-leu. Relative protein synthesis, independent of alterations in $\mathrm{TU}$, was expressed by the ratio PI/TU $\times 100$. Delayed fetal effects of acute maternal ethanol exposure were studied by injecting the fetal amniotic sacs with $\left.\right|^{3} \mathrm{H} \mid \mathrm{L}$-leu $24 \mathrm{hr}$ after maternal ethanol administration.

Both TU andPI were decreased in high dose fetal brain. Liver PI, but not TU, was depressed. High dose ethanol treatment caused a reduction in protein synthesis $(P I / T U \times 100)$ in fetal brain, but not liver. Low dose ethanol enhanced brain PI and both liver and brain PI/TU $\times 100$. Utilization of $\left[{ }^{3} \mathrm{H} \mid \mathrm{L}\right.$-leu was related to fourth-hour (sacrifice) maternal serum ethanol levels. Fetal brain was more strikingly affected than liver. Ethanol concentrations $>200 \mathrm{mg} / \mathrm{dl}$ caused a decrease in brain TU (control, 1879 \pm 185 versus ethanol, $1219 \pm 123 \mathrm{dpm} / \mathrm{mg}$ protein) and $\mathrm{PI} / \mathrm{TU} \times$ 100 (control, $48.9 \pm 3.3$ versus ethanol, $31.5 \pm 2.9$ ). At levels $<100$ $\mathrm{mg} / \mathrm{dl}, \mathrm{PI} / \mathrm{TU} \times 100$ was enhanced in both brain (control, $48.9 \pm$ 3.3 versus ethanol, $67.3 \pm 2.8$ ) and liver (control, $45.3 \pm 4.2$ versus ethanol, $62.3 \pm 1.7)$. Tissue uptake of $\left[{ }^{3} \mathrm{H} \mid \mathrm{L}\right.$-leu $24 \mathrm{hr}$ after high dose maternal ethanol exposure was increased in fetal brain.

The results support the hypothesis that a brief period of maternal/fetal ethanol exposure, similar to that found in "social" drinking humans, alters normal fetal metabolism.
\end{abstract}

\section{Speculation}

Chronic maternal ethanol abuse is harmful to the human fetus, but the fetal risks of acute or "social" ethanol consumption are undefined. The observation of altered rat fetal utilization of leucine both during and $24 \mathrm{hr}$ after acute maternal ethanol administration suggests that even a brief period of ethanol exposure is potentially harmful to the fetus. The long-term effects of such exposure upon fetal and neonatal growth and development remain to be determined.

Alcohol abuse is a major health problem worldwide. Not only is the health of those who imbibe ethyl alcohol (ethanol) adversely affected, but the fetus is also susceptible to the ill effects of maternal ethanol ingestion. Being a small molecule, ethanol freely crosses the placenta and the consequences of chronic maternal ethanol abuse may be manifested in the infant as the fetal alcohol syndrome (FAS) (4). Mental retardation, a particularly disturbing aspect of the FAS, occurs in approximately $80 \%$ of the cases. The pathophysiology of the FAS, including mental deficiency, is not understood completely, although it is felt to be related to the direct toxic effects of ethanol or its metabolities $(4,25)$. Because the FAS occurs primarily in the offspring of chronically alcoholic mothers, most laboratory investigations have concentrated on the effects of chronic ethanol exposure upon the fetus. Using animal models of chronic ethanolism, gross anatomic abnormalities, postnatal behavioral changes, and alterations in fetal central nervous system metabolism have been demonstrated $(3,12,21,22,32)$.

Although it appears that chronic maternal ethanol ingestion results in fetal injury, little attention has been directed toward an evaluation of the effects of brief or infrequent "social" maternal ethanol consumption upon the fetus. Such studies would be of interest because relatively few pregnant women are chronic alcoholics, although many ingest ethanol either once or infrequently during their pregnancy. The risk to the fetus of common. "socially acceptable" maternal alcohol consumption is as yet undefined. Some population studies have suggested that "moderate" maternal intake ( 30 to $60 \mathrm{ml}$ absolute ethanol per day) may be harmful to the fetus $(6,9)$. Other investigations are less conclusive $(20,26)$. The possibility exists that social ethanol consumption could adversely affect the human fetus, particularly at a biochemical level. without causing sufficient overt damage so as to cause the child to be recognized as having the FAS. Therefore, to begin to define the biochemical effects of brief ethanol exposure upon the fetus. we have developed an animal model for the evaluation of in vivo metabolic function during acute maternal ethanol administration.

\section{MATERIALS AND METHODS}

Nonpregnant and pregnant (obtained at 15 days gestation) Sprague-Dawley descended rats were purchased from Charles River Company (Wilmington. MA) and maintained on routine lab chow. Tritiated L-leucine $\left[{ }^{3} \mathrm{H}\right] \mathrm{L}-\mathrm{leu}(110 \mathrm{Ci} / \mathrm{mole})\left[{ }^{14} \mathrm{C}\right]$ carboxyldextran $(1.11 \mathrm{mCi} / \mathrm{g})$, molecular weight $=70,000$, and hyamine hydroxide were obtained from New England Nuclear Corporation (Boston, MA). Scintillation fluid was purchased from AmershamSearle (Arlington Heights, IL).

At 19 days gestation, the pregnant rats received an intraperitoneal injection of $47.5 \%$ ethanol $(\mathrm{v} / \mathrm{v})$ in normal saline solution (NS). The "high dose" group received 0.61 to $0.67 \mathrm{ml} / 100 \mathrm{~g}$ body weight (BW) (maximum, $2.5 \mathrm{ml}$ ) and the "low dose" mothers were administered 0.16 to $0.18 \mathrm{ml} / 100 \mathrm{~g} \mathrm{BW}$. Control animals were given NS. One hr after maternal ethanol injection (time $=1 \mathrm{hr}$ ) intra-amniotic injection of $\left[{ }^{3} \mathrm{H}\right] \mathrm{L}$-leu was performed according to a modification of the methods of Lev and Orlic (14). The uterus was exposed during light other anesthesia and $1.0 \mu \mathrm{Ci}\left[{ }^{3} \mathrm{H}\right] \mathrm{I}$-leu in $0.1 \mathrm{ml} \mathrm{NS}$ was injected via a 26-gauge needle into the amniotic fluid of two to four fetuses in one uterine horn. The maternal abdomen was closed, and $1 \mathrm{hr}$ later (time $=2 \mathrm{hr}$ ), the mothers received an additional intraperitoneal injection of ethanol or saline 
( 0.16 to $0.18 \mathrm{ml} / 100 \mathrm{~g} \mathrm{BW}$ ). The cumulative ethanol dose was, therefore, 0.29 to $0.33 \mathrm{~g} / 100 \mathrm{~g} \mathrm{BW}$ and 0.12 to $0.14 \mathrm{gm} / 100 \mathrm{~g} \mathrm{BW}$ for the high and low groups, respectively.

Three hr after the intra-amniotic injection of $\left[{ }^{3} \mathrm{H}\right] \mathrm{L}$-leu (time $=$ $4 \mathrm{hr}$ ), the animals were sacrificed. Maternal serum was obtained for determination of radioactivity and ethanol concentration (standard enzymatic method utilizing alcohol dehydrogenase) (1). All injected fetuses and at least one noninjected fetus from the opposite uterine horn were removed. The fetal brain and most of the liver were excised, and each tissue was homogenized in $1.5 \mathrm{ml} \mathrm{NS}$ using a Teflon and glass homogenizer.

Protein content of the homogenate was determined by the method of Lowry et al. (17). For analysis of tissue radioactivity [tissue uptake (TU)], aliquots were incubated overnight with 0.5 $\mathrm{ml}$ hyamine hydroxide at $60^{\circ} \mathrm{C}$, after which scintillation fluid and glacial acetic acid were added, and the solution was counted in a Packard Tri-Carb Spectrometer (Packard Instrument Co., Downers Grove, IL). Incorporation of $\left[{ }^{3} \mathrm{H}\right] \mathrm{L}$-leu into protein (PI) was determined by adding $10 \%$ trichloroacetic acid to aliquots immediately after homogenization and processing according to the methods of Villa-Trevino et al. (30). Results for both TU and PI were expressed as disintegrations per min (dpm) per $\mathrm{mg}$ protein. Protein synthesis was estimated by expressing PI as a percentage of TU $(\mathrm{PI} / \mathrm{TU} \times 100)$.

Delayed fetal effects of acute maternal ethanol exposure were studied in three rats, each receiving high dose ethanol at 18 days of gestation. Twenty-four hr later, $\left[{ }^{3} \mathrm{H}\right] \mathrm{L}$-leu $(1.0 \mu \mathrm{Ci})$ was injected into the amniotic sacs. The animals were sacrificed $3 \mathrm{hr}$ after intra-amniotic injection and tissues were processed as above.

Ethanol effects upon fetal swallowing were evaluated in both high and low dose treated animals. Instead of $\left[{ }^{3} \mathrm{H}\right] \mathrm{L}$-leu, the poorly absorbable marker $\left[{ }^{14} \mathrm{C}\right]$ carboxyldextran $(1 \mu \mathrm{Ci}$ in $0.1 \mathrm{ml} \mathrm{NS})$ was injected into the amniotic sac. The stomach and the intestine were removed separately from each fetus, homogenized, and processed as above for determination of total radioactivity per organ.

All results are expressed as the mean \pm S.E. Statistical analysis utilized Student's $t$ test (2-tailed) for grouped or paired data. Results are considered probably different for $P<0.05$ and significantly different for $P<0.02$.

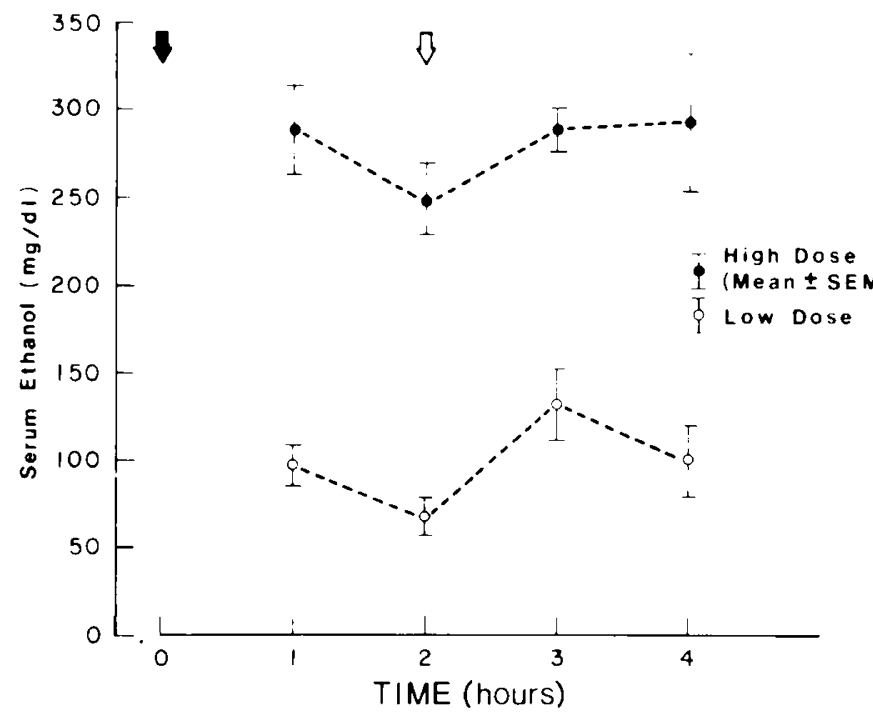

Fig. 1. Blood ethanol levels from 1 to $4 \mathrm{hr}$ after intraperitoneal injection. Nonpregnant rats weighing 250 to $270 \mathrm{~g}$ received ethanol at a high $(0.26 \mathrm{~g} / 100 \mathrm{~g}$ body weight: $n=9)$ or low dose $(0.06 \mathrm{~g} / 100 \mathrm{~g}$ body weight: $n=7$ ) at time $=0$ (closed arrow). Ethanol was administered again $(0.06 \mathrm{~g}$ ) $100 \mathrm{~g}$ body weight) at time $=2 \mathrm{hr}$ (open arrow) just after blood was obtained. Fourth-hour values differed from levels at earlier times only at $2 \mathrm{hr}$, low dose.

\section{RESULTS}

Mean maternal serum ethanol concentrations at the time of sacrifice were $297.9 \pm 36.5 \mathrm{mg} / \mathrm{dl}$ (range, 162 to $406 \mathrm{mg} / \mathrm{dl} ; n=$ 6) for the high dose and $94.2 \pm 27.5 \mathrm{mg} / \mathrm{dl}$ (range, 11 to $172 \mathrm{mg}$ / $\mathrm{dl} ; n=6$ ) for the "low dose" group. Within a group of nonpregnant rats, fourth-hr serum ethanol concentrations were found to roughly reflect earlier levels (Fig. 1). For both ethanol doses, the mean fourth hour value for the experimental pregnant rats was essentially the same as that for the corresponding nonpregnant animals.

Swallowing activity was reduced in high dose fetuses (9559 \pm $2494 \mathrm{dpm}\left[{ }^{14} \mathrm{C}\right]$ carboxyldextran per stomach; $\left.n=16\right)$ compared to the saline controls $(21,761 \pm 2680 \mathrm{dpm}$ per stomach; $n=42)(P$ $<0.01)$. For low dose animals, fetal stomachs contained greater amounts of $\left[{ }^{14} \mathrm{C}\right]$ carboxyldextran $(28,877 \pm 4378 \mathrm{dpm}$ per stomach: $n=18$ ), but this value did not differ significantly from saline controls $(P>0.15)$. Relatively little $\left[{ }^{14} \mathrm{C}\right]$ carboxyldextran was found in the intestine. There was no difference in intestinal content of $\left[{ }^{14} \mathrm{C}\right]$ carboxyldextran between controls $(440 \pm 92.5 \mathrm{dpm}$ per intestine) and either "high" (322 $\pm 119.2 \mathrm{dpm}$ per intestine) or low dose $(519 \pm 99.1 \mathrm{dpm}$ per intestine) fetuses.

The radiolabel, injected into the amniotic fluid as $\left[{ }^{3} \mathrm{H}\right] \mathrm{L}-$ leucine entered the maternal circulation as well as fetal tissue. Maternal serum radioactivity did not differ significantly between groups: control, $2035 \pm 289 \mathrm{dpm} / \mathrm{ml}$; high dose, $1578 \pm 113 \mathrm{dpm} / \mathrm{ml}$; low dose, $2102 \pm 275 \mathrm{dpm} / \mathrm{ml}$. Tissue radioactivity in brain and liver in noninjected fetuses, obtained from the opposite uterine horn, was $₹ 10 \%$ of that from injected ones.

Both TU and PI were decreased $(P<0.005)$ in high dose fetal

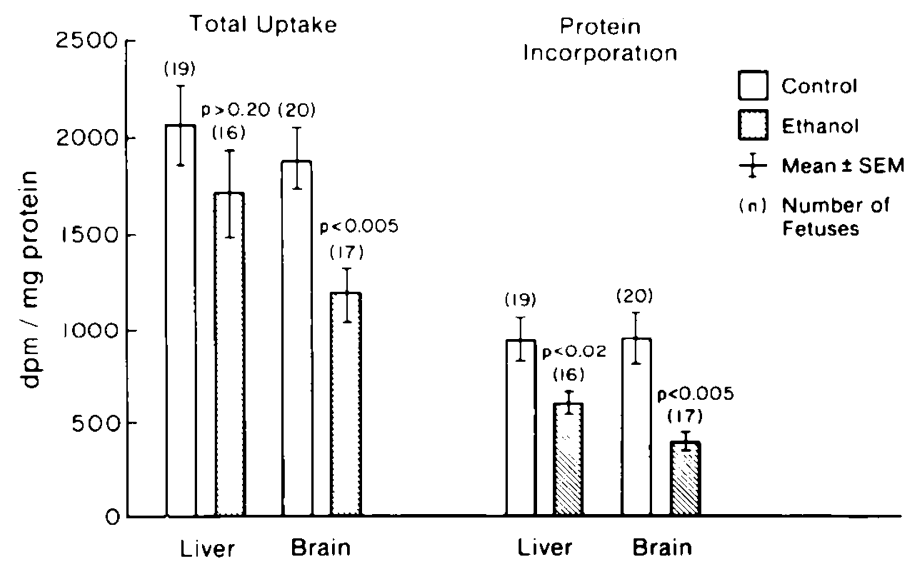

Fig. 2. Effect of high dose ethanol upon tissue uptake of $\left[{ }^{3} \mathrm{H}\right] \mathrm{L}$-leu and incorporation into protein.

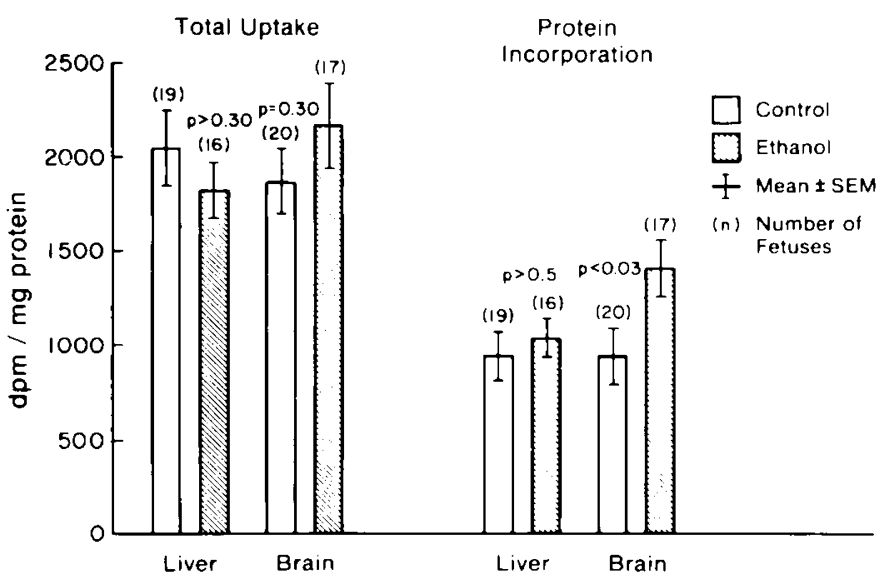

Fig. 3. Effect of low dose ethanol upon tissue uptake of $\left[{ }^{3} \mathrm{H}\right] \mathrm{L}-$ leu and incorporation into protein. 
brain (Fig. 2). For liver, TU was not significantly diminished ( $P$ $>0.2)$ whereas PI was significantly depressed $(P<0.02)$ (Fig. 2 ). In the low dose fetuses, there was no alteration in hepatic TU and PI, nor brain TU $(P>0.3)$, although brain PI was enhanced $(P$ $<0.03$ ) (Fig. 3). High dose ethanol treatment caused a reduction in protein synthesis, expressed as the ratio $\mathrm{PI} / \mathrm{TU} \times 100$, which was significant in fetal brain $(P<0.001)$, but not in liver $(P=$ 0.07 ) (Fig. 4). In contrast, tissue from low dose fetuses exhibited increased protein synthesis for brain $(P<0.001)$ and liver $(P=$ 0.04) (Fig. 4).

Utilization of $\left[{ }^{3} \mathrm{H}\right] \mathrm{L}$-leu was related to fourth-hour maternal serum ethanol levels (Table 1; Fig. 5). Tissue uptake of radioactivity and protein synthesis $(\mathrm{PI} / \mathrm{TU} \times 100)$ were significantly decreased only in brain when the fourth-hr maternal ethanol concentrations were $>200 \mathrm{mg} / \mathrm{dl}$. At 100 to $200 \mathrm{mg} / \mathrm{dl}$ and $<100$ $\mathrm{mg} / \mathrm{dl}$, there was no alteration in $\mathrm{TU}$ in either tissue. However, $\mathrm{PI} / \mathrm{TU} \times 100$ was significantly elevated in both liver and brain at ethanol levels $<100 \mathrm{mg} / \mathrm{dl}$.

Analysis of $\left[{ }^{3} \mathrm{H}\right]_{\mathrm{L}}$-leu uptake $24 \mathrm{hr}$ after high dose ethanol exposure showed a significant increase in TU for brain, but not liver $($ Fig. 6). Protein synthesis $(\mathrm{PI} / \mathrm{TU} \times 100)$ was unaffected in both liver (control, $45.3 \pm 4.2$ versus ethanol, $38.0 \pm 8.0$ ) and brain (control $48.9 \pm 3.3$ versus ethanol $50.5 \pm 2.5$ ).

\section{DISCUSSION}

This study demonstrates that a single, brief (4-hr) period of maternal/fetal ethanol exposure alters in vivo fetal tissue uptake and incorporation into protein of the essential amino acid, leucine. Leucine was selected as the radiolabeled substrate because it is readily incorporated into protein and its membrane transport is well defined. Tissue uptake of leucine is a membrane-associated,

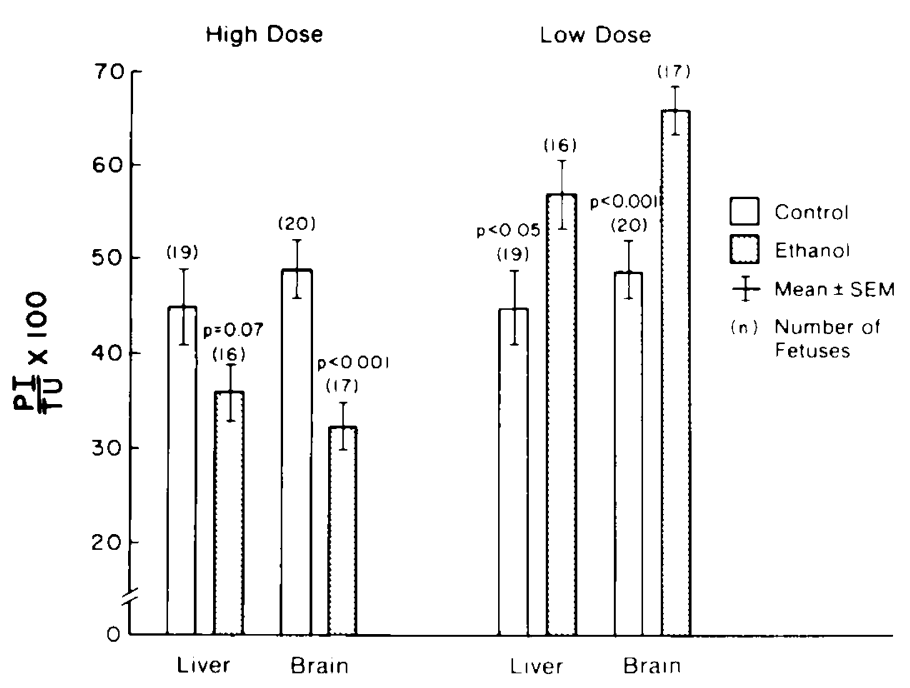

Fig. 4. Effect of ethanol upon protein synthesis.

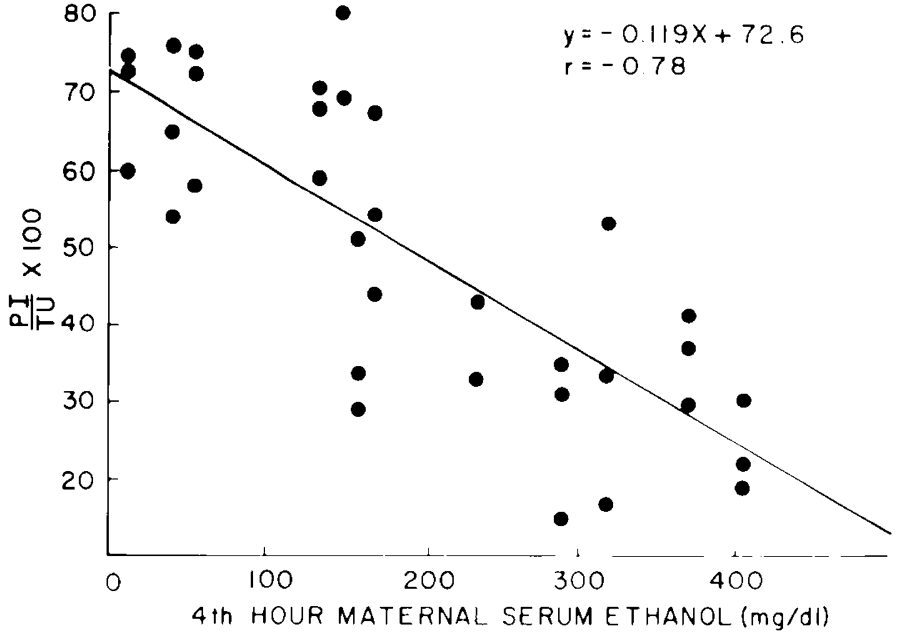

Fig. 5. Fourth-hr maternal serum ethanol levels and fetal rat brain protein synthesis.

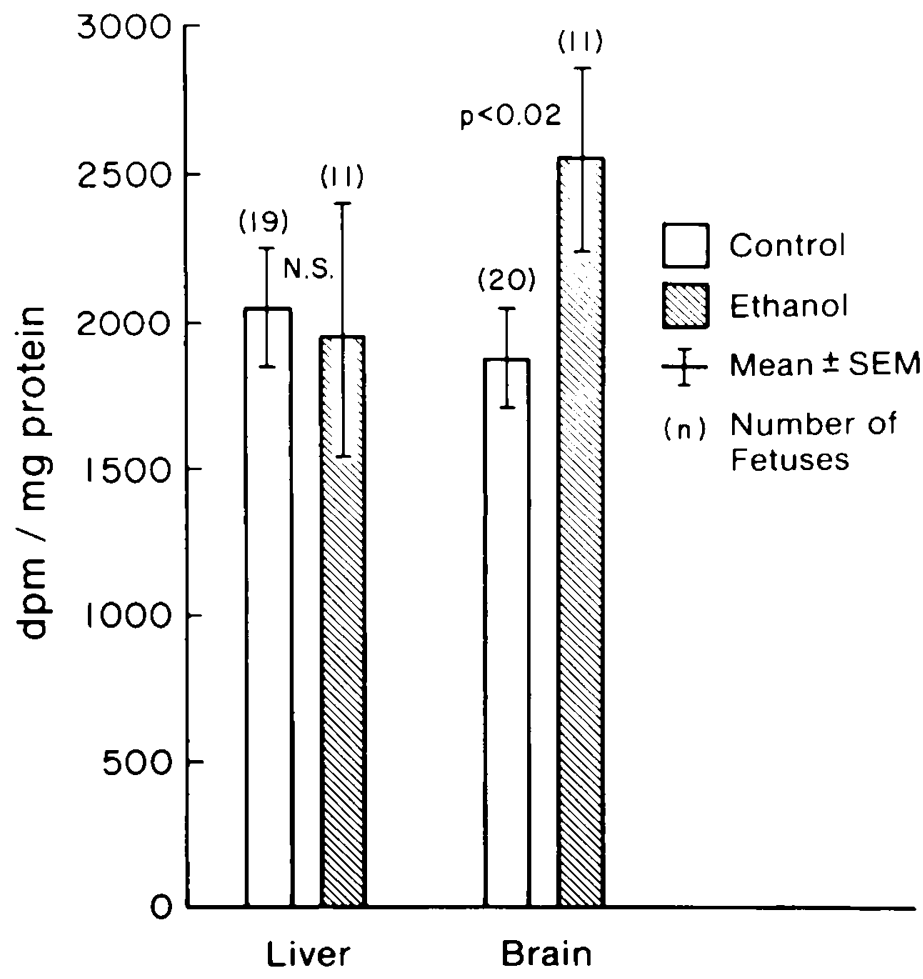

Fig. 6. Tissue uptake of $\left[{ }^{3} \mathrm{H}\right] \mathrm{L}-\mathrm{-leu} 24 \mathrm{hr}$ after high dose ethanol exposure.

Table 1. Fourth-hr maternal serum ethanol concentrations and fetal utilization of $\left.{ }^{3} \mathrm{H}\right]-\mathrm{L}-\mathrm{leu}$

\begin{tabular}{|c|c|c|c|c|c|c|}
\hline $\begin{array}{c}\begin{array}{c}\text { Maternal } \\
\text { fourth-hr }\end{array} \\
\text { serum ethanol }\end{array}$ & $\begin{array}{c}\text { No. } \\
\text { fetuses }\end{array}$ & $\begin{array}{c}\text { Brain } \\
\text { [tissue } \\
\text { uptake } \\
(\mathrm{dpm} / \mathrm{mg} \text { protein })]\end{array}$ & $\mathrm{PT} / \mathrm{TU} \times 100$ & $\begin{array}{l}\text { No. of } \\
\text { fetuses }\end{array}$ & $\begin{array}{c}\text { Liver } \\
\text { [tissue } \\
\text { uptake } \\
(\mathrm{dpm} / \mathrm{mg} \text { protein })]\end{array}$ & $\mathrm{PI} / \mathrm{TU} \times 100$ \\
\hline Control & 20 & $1879 \pm 185^{1}$ & $48.9 \pm 3.3$ & 19 & $2040 \pm 209$ & $45.3 \pm 4.2$ \\
\hline$>200 \mathrm{mg} / \mathrm{dl}$ & 14 & $1219 \pm 123^{2}$ & $31.5 \pm 2.9^{3}$ & 13 & $1579 \pm 227^{4}$ & $37.4 \pm 3.1^{4}$ \\
\hline $100-200 \mathrm{mg} / \mathrm{dl}$ & 11 & $2131 \pm 331^{4}$ & $57.2 \pm 5.2^{4}$ & 10 & $1973 \pm 242^{4}$ & $43.5 \pm 5.8^{4}$ \\
\hline$<100 \mathrm{mg} / \mathrm{dl}$ & 9 & $1870 \pm 206^{4}$ & $67.3 \pm 2.8^{3}$ & 9 & $1989 \pm 147^{4}$ & $62.3 \pm 1.7^{3}$ \\
\hline
\end{tabular}

${ }^{1}$ Mean \pm S.E.

${ }^{2} P<0.01$.

${ }^{3} P<0.001$.

${ }^{4}$ Not significant, $P>0.10$. 
energy-dependent active transport process (18). One mechanism by which ethanol might affect leucine transport would be interacton with the hydrophobic regions of the cell membrane (29). Such interaction would be expected to interfere with amino acid transport (31), as was observed in fetal rat brain at ethanol levels in excess of $200 \mathrm{mg} / \mathrm{dl}$. In addition, energy for leucine transported is dependent in part upon membrane-associated $\mathrm{Na}^{+} / \mathrm{K}^{+}$-ATPase, the activity of which has been shown to be acutely reduced by ethanol in both neuronal and gastrointestinal tissue $(8,16)$. Yet another mechanism by which alcohol might interfere with leucine transport would be a change in the cellular redox state (increased $\mathrm{NADH}_{2}$ ), resulting from ethanol oxidation. This explanation might be applicable in fetal rat liver, where alcohol dehydrogenase is present as early as 12 days gestation (23). However, it is not likely to apply to the fetal brain, where essentially to ethanol oxidation occurs (2).

Because ethanol did not affect the tissue uptake of leucine, particularly in the brain, changes in protein incorporation of radiolabel might merely have been the result of the altered uptake. It was postulated that the level of uptake of radioactivity would determine the intracellular amino acid pool available for protein synthesis in that tissue. The ratio of radioactivity incorporated into tissue uptake $(\mathrm{PI} / \mathrm{TU} \times 100)$ would therefore reflect protein synthesis, independent of any alterations in uptake. Using this correction, it is evident that high maternal serum ethanol concentrations $(200 \mathrm{mg} / \mathrm{dl})$ inhibit fetal protein synthesis, with the effect being more pronounced in central nervous system tissue than in liver. These results may have been due to ethanol intereference with membrane dependent ribosomal function, a phenomenon which has been observed in the rat following chronic alcoholic administration $(10,11)$. Ethanol may also have interfered with amino acylation of t-RNA (11). In the liver, oxidative metabolites of ethanol $(19,28)$ or a change in redox state $(24)$ may have affected protein synthesis, but this would not have occurred in central nervous system tissue where there is an absence of ethanol oxidation. The enhancement of protein synthesis at lower ethanol levels remain unexplained. Relevant to this finding, however, it should be noted that chronic alcohol exposure has been shown to increase nonmembrane dependent ribosomal protein synthesis in rat liver $(10,11)$.

Our experiments were aimed at the effects of acute maternal/ fetal ethanol administration because this would more closely approximate the situation in the nonalcoholic, social drinking human. Clearly, however, our model differs in certain aspects from the human experience. The animals were exposed to ether as well as ethanol, increasing the potential for fetal hypoxia, especially at the higher ethanol dose. In addition, the ethanol was administered in high concentration by the intraperitoneal route, which might have been a painful stimulus for release of maternal catecholamines and, hence, altered fetal blood flow. Nonetheless, the mothers were arousable at both ethanol doses and the fetuses were pink and responsive to stimulation at sacrifice.

It had previously been demonstrated that a single intraperitoneal dose of ethanol, capable of rendering a pregnant mouse comatose for up to 4 hours, resulted in gross anatomic fetal abnormalities and fetal death (13). Because maternal blood levels of ethanol were not measured in that study, direct comparison to our investigation is difficult. In a more recent study, Henderson et al. (7) gave ethanol by gavage to pregnant rats for 3 days. At the end of the 3-day period, the concentration of ethanol in maternal sera had reached the relative high mean level of $380 \mathrm{mg} / \mathrm{dl}$. Under such conditions, which would be more similar to those found in chronically alcoholic humans, decreased fetal organ weight and DNA content were observed. Those investigators found a significant effect of ethanol upon fetal brain when treatment was from 14 to 16 days of gestation, but not earlier. This finding of a critical time for ethanol-associated fetal brain injury could be related to the period of neuronal proliferation in the developing rat, which begins during the last week of a 21-day gestational period and peaks in the first week postpartum (5). In the human, the com- parable period of neuronal growth would be the late first and early second trimesters (5).

Although the results of the two aforementioned studies are consistent with the findings of this investigation, neither provides any insight into possible metabolic factors responsible for the abnormalities observed, nor was there any variation in the ethanol dose utilized. In contrast, our animal model permits in vivo evaluation of fetal metabolism at a time of fetal neuronal proliferation, with variation in both the dose and timing of maternal/fetal ethanol treatment. The intra-amniotically injected radiolable was assumed to enter the injected fetus by two means: (1) swallowing with subsequent intestinal absorption; and (2) direct absorption into the fetal circulation via the fetal membranes. Our data indicates that rat fetal swallowing was diminished by high dose ethanol. This would be analogous to depressions in human fetal breathing during maternal ethanol ingestion (15). Regardless of the changes in fetal swallowing activity, very little radioactivity entered the fetal intestine. Therefore, we assume that the majority of radiolabel was directly absorbed into the fetuses via the fetal membranes. Maternal serum uptake from the amniotic fluid and subsequent placental transport back to the fetus could account for no more than $10 \%$ of fetal tissue radioactivity.

Although the highest maternal serum ethanol concentrations $(>200 \mathrm{mg} / \mathrm{dl}$ ) had the greatest influence upon leucine utilization, it must be emphasized that test tissue values differed from controls even at levels below $100 \mathrm{mg} / \mathrm{dl}$. Such serum concentrations are frequently found in social drinkers (27), and $100 \mathrm{mg} / \mathrm{dl}$ is the legal definition of intoxication in the United States. Whether or not the one-time alterations in leucine utilization demonstrated in this investigation will prove to result in any long-term effects upon rat fetal organ development remains to be determined. Nonetheless, the results support the hypothesis that a brief period of maternal/ fetal ethanol exposure, regardless of alcohol dosage, alters normal fetal metabolism.

The number of such exposures necessary to irreversibly affect the fetus and the ability of the fetus to compensate or "rebound" from short periods of metabolic injury is unknown. We would speculate, however, that the increased fetal brain uptake of leucine, which occurred $24 \mathrm{hr}$ after ethanol treatment, could represent some form of compensatory reaction. Under the constraints of our animal model, the fetal rat brain was more susceptible to the influence of ethanol than the liver-a finding which parallels the preponderance of mental deficiency and clinical absence of hepatic disease in the FAS.

\section{REFERENCES AND NOTES}

1. Bauer, J. D.. Ackermann. P. G.. and Toro, G.: Methods in toxicology poisons and drugs. In: Clinical Laboratory Methods, pp. 787-790 (C. V. Mosby Co., Saint Louis, 1974).

2. Chambers, J. W., and Piccirillo V. J.: Effects of ethanol on amino acid uptake and utilization by the liver and other organs of rats. Q. J. Stud. Alcohol, 34: 707 (1973).

3. Chernoff, G. F.: The fetal alcohol syndrome in mice: An animal model. Teratology. 15: 223 (1977).

4. Clarren. S. K.. and Smith. D. W.: The fetal alcohol syndrome. N. Engl. J. Med.. 298: 1063 (1978).

5. Dobbing. J. A.: Vulnerable periods of brain development. In Lipids. Malnutrition and the Developing Brain. pp. 9-19 (Associated Scientific Publishers. New York, 1972).

6. Hanson. J. W., Streissguth. A. P., and Smith. D. W.: The effects of moderate alcohol consumption during pregnancy on fetal growth and morphogenesis. J. Pediatr., 92: 457 (1978).

7. Henderson, G. I., Hoyumpa. A. M., McClain, C., and Schenker. S.: The effects of chronic and acute alcohol administration on fetal development in rat. Alcoholism. Clin. Exp. Res.. 3: 99 (1979).

8. Hoyumpa. A. M.. Nichols. S. G.. Wilson. F. A.. and Schenker, S.: Effects of ethanol on intestinal ( $\mathrm{Na} . \mathrm{K}$ ) ATPase and intestinal thiamine transport in rats. J. Lab. Clin. Med., 90: 1088 (1977).

9. Kaminski. M., Rumeau-Rouquette, C.. and Schwartz. D.: Consommation d'alcool chez. les femmes enceintes at issue de la grossesse. Rev. Epidemiol. Med. Soc. Sante Publique. 24: 27 (1976).

10. Khawaja, J. A., Lindholm, D. B., and Niittyla, J.: Selective inhibition of protein synthetic activity of cerebral membrane-bound ribosomes as a consequence of ethanol ingestion. Res. Commun. Chem. Pathol. Pharmacol., 19: 185 (1978).

11. Khawaja. J. A., and Lindholm, D. B.: Differential effect of ethanol ingestion on 
the protein synthetic activities of free and membrane-bound ribosomes from liver of the weanling rat. Res. Commun. Chem. Pathol. Pharmacol., 19: 129 (1978).

12. Khawaja, J. A., Wallgren. H.. Usmi, H., and Hilska, P.: Neuronal and liver protein synthesis in the developing offspring following treatment of pregnant rats with ethanol or 1,3-butanediol. Res Commun. Chem. Pathol. Pharmacol. 22: 573 (1978).

13. Kronick, J. B.: Teratogenic effects of ethyl alcohol administered to pregnant mice. Am. J. Obstet. Gynecol., 124: 676 (1976).

14. Lev, R., and Orlic. D.: Protein absorption by the intestine of the fetal rat in utero. Science (Wash. D. C.). 177: 522 (1972)

15. Lewis, P. J., and Boylan, P.: Alcohol and fetal breathing. Lancet, 1: 388 (1979)

16. Lin, D. C.: Effect of ethanol on the kinetic parameters of brain $\left(\mathrm{Na}^{+}+\mathrm{K}^{+}\right)$ activated adenosine triphosphatase. Ann. N. Y. Acad. Sci.. 273: 331 (1976).

17. Lowry, O. H., Rosebrough, N. J., Farr, A. L., and Randall, R. J.: Protein measurement with the Folin phenol reagent. J. Biol. Chem., 193: 265 (195I).

18. Miller, R. K., and Berndt, W. O.: Characterization of neutral amino acid accumulation by human term placental slices. Am. J. Physiol., 227: 1236 (1974).

19. Moreland, J., Bressesen, A., and Svenson, L.: Incorporation of labelled amino acids into protein of isolated parencnymal and nonparenchymal rat liver cells in the absence and presence of ethanol. Biochem. Biophys. Acta, 561: 464 (1979).

20. Ouelette, E. M., Rosett, H. L., Rosman, N. P., and Weiner, L. Adverse effects on offspring of maternal alcohol abuse during pregnancy. N. Engl. J. Med., 297: 528 (1977).

21. Randall. C.. Taylor. W., and Walker, D.: Ethanol-induced malformations in mice. Alcohol. Clin. Exp. Res., I: 219 (1977)

22. Rawat, A. K.: Ribosomal protein synthesis in the fetal and neonatal rat brain as influenced by maternal ethanol consumption. Res. Commun. Chem. Pathol. Pharmacol., 12: 723 (1975).

23. Rawat, A. K.: Effect of maternal ethanol consumption on fetal hepatic metabo-

Copyright (1) 1981 International Pediatric Research Foundation, Inc. $0031-3998 / 81 / 1504-0335 \$ 02.00 / 0$ lism in the rat. Ann. N. Y. Acad Sci. 273: 175 (1976).

24. Rawat, A. K.: Effect of maternal ethanol consumption on foetal and neonatal rat hepatic protein synthesis. Biochem. J., 160: 653 (1976).

25. Rawat, A. K.: Fetal alcohol syndrome metabolic abnormalities. Ohio State Med. J., 74: 109 (1978).

26. Rosett, H. L., Ouelette, E., Weiner, L., and Owens. E.: The prenatal clinic: a site for alcoholism prevention and treatment, In: F. A. Sexias: Currents in Alcoholism. Vol. 1, pp. 417-430 (Grune \& Stratton. New York, 1977).

27. Short R. G., and Vogel-Sprott, M. D.: Social drinkers' self-regulation of alcohol intake. J. Stud. Alcohol, 39: 1290 (1978)

28. Sorrel, M. F.. Tuma. D., and Barak. A. J.: Evidence that acetaldehyde irreversibly impairs glycoprotein metabolism in liver slices. Gastroenterology, 73: 138 (1977).

29. Sun, A. Y., and Samorajski, T.: Effects of ethanol on the activity of adenosine triphosphatase and acetylcholinesterase in synaptosomes isolated from guineapig brain. J. Neurochem, 17: 1365 (1970).

30. Villa-Trevino, S., Skull. K. H., and Farber. F. The role of adenosine triphosphate deficiency in ethionine-induced inhibition of protein synthesis. J. Biol. Chem. 238: 1757 (1963)

31. Wilson, F. A., and Hoyumpa. A. M.. Jr.: Ethanol and small intestinal transport. Gastroenterology, 76: 388 (1979).

32. Yanai, J., Sze, P. Y., and Ginsburg, B. E.: Differential induction of behavioral and metabolic changes by ethanol during early development. Behav. Genet. 5: 111 (1975).

33. Presented in part at the annual meeting, society for Pediatric Research. Atlanta. GA, May, 1979, and the Medical Scientific Concerence of the National Alcoholism Forum, Seattle, WA, May, 1980.

34. Requests for reprints should be addressed to: Stanley E. Fisher, M.D.. Director of Pediatric Gastroenterology, Children`s Hospital of Pittsburgh. 125 De Soto of Pediatric Gastroenterology, Childrer
Street. Pittsburgh. PA 15213 (USA)

35. Received for publication March 15,1980

36. Accepted for publication August 29. 1980. 